\title{
PERILAKU PENGGUNAAN ALAT PELINDUNG DIRI DAN PENULARAN PENYAKIT KULIT PADA PETUGAS TPS DI KECAMATAN SAWAHAN SURABAYA
}

\author{
NI PUTU RUSMINI \\ AKADEMI KEPERAWATAN ADI HUSADA \\ puturusmini2015@gmail.com
}

\begin{abstract}
ABSTRAK
Petugas TPS atau petugas pengangkut sampah merupakan pekerja yang setiap harinya mengambil atau mengangkut sampah dari rumah ke rumah untuk dikumpulkan kemudian di pilah-pilah di TPS dan akan dikirimkan ke tempat pembuangan yang lebih besar yaitu Tempat Pembuangan Akhir (TPA). Sepanjang hari petugas TPS bekerja dengan sampah sehingga membuat mereka mempunyai risiko tinggi terkena penularan penyakit kulit, baik yang memiliki efek secara langsung maupun tidak langsung. Salah satu upaya yang dapat dilakukan untuk mengurangi resiko terkena penularan penyakit kulit adalah dengan menggunakan Alat Pelindung Diri (APD) Kurangnya kesadaran, kepatuhan dan informasi tentang risiko bahaya, sebagian dari mereka tidak tidak menggunakan APD. APD yang kurang lengkap dapat memungkinkan kontak langsung dengan sampah sehingga mengakibatkan terjadinya gangguan kesehatan salah satunya yaitu menyebabkan penularan penyakit kulit. Jenis penelitian ini adalah analitik korelasi dengan pendekatan cross-sectional. Data diuji dengan Spearman rank test. Pengumpulan data dengan cara observasi, wawancara dan kuesioner. Peneliti menggunakan metode total sampling. Hasil uji statistik menunjukkan $\mathrm{p}=0.00$ $(\alpha<0.05)$ dan $\mathrm{r}=0.761$, sehingga terdapat hubungan yang kuat antara perilaku pemakaian APD dengan penularan penyakit kulit pada petugas TPS. Oleh sebab itu, diharapkan program pemerintah dan petugas kesehatan dapat mendukung penggunaan APD sebagai upaya preventif terhadap penularan penyakit kulit pada petugas TPS.
\end{abstract}

Kata kunci : sampah, petugas TPS, alat pelindung diri (APD), penularan penyakit kulit

\begin{abstract}
A garbage worker who take or hauling garbage from house to house and collected and then sorted into the TPS every day and will be sent to landfills larger is the final disposal (landfill). Throughout the day poll workers working with litter so as to make them have a higher risk of skin disease transmission, both of which have the effect of directly or indirectly. One effort that can be done to reduce the risk of skin disease transmission is to use Personal Protective Equipment (PPE) Lack of awareness, compliance and information about the risk of harm, some of them not using PPE. APD incomplete can allow direct contact with garbage, which causes health problems one of which causes the skin disease transmission. This type of research is an analytic correlation with cross-sectional approach. Data were tested with Spearman rank test. The collection of data by means of observation, interviews and questionnaires. Researchers used total sampling method. Statistical analysis showed $p=0.00(\alpha<0,05)$ and $r=0.761$, so there is a strong relationship between the behavior of the use of PPE with the skin disease transmission at the polling station officials. Therefore, it is expected the government programs and health workers can support the use of PPE as a preventative measure against the spread of skin disease at polling station officials.
\end{abstract}

Keywords: garbage, garbage workers, Personal Protective Equipment (PPE), skin disease transmission. 


\section{PENDAHULUAN}

Masalah kesehatan merupakan suatu masalah yang sangat kompleks, yang saling berkaitan dengan masalah-masalah lain di luar kesehatan itu sendiri. Petugas Tempat Pembuangan sementara (TPS) umumnya ketika bekerja kurang menjaga kebersihan dirinya, antara lain tidak menggunakan alat pelindung diri (APD) seperti: helmet, sepatu boot, sarung tangan, dan masker. Bagian tubuh yang tidak terlindungi oleh alat pelindung diri dapat memicu perkembangbiakan bakteri pada kulit yang berasal dari sampah yang dikelola oleh petugas tersebut. ${ }^{1}$ Masalah yang ditimbulkan juga akan berdampak bagi kesehatan petugas, seperti timbulnya berbagai penyakit yang dapat menurunkan kualitas atau tingkat kesehatan petugas TPS. Penyakit kulit merupakan masalah utama yang sering didapatkan oleh para petugas TPS yang seringkali bekerja tanpa menggunakan APD dengan baik dan benar. Saat ini pembanguan di Indonesia semakin berkembang. ${ }^{4}$ Menurut WHO (2002), sampah yaitu sesuatu yang tidak digunakan, tidak terpakai, tidak disenangi, atau sesuatu yang dibuang yang berasal dari kegiatan manusia dan tidak terjadi dengan sendirinya. Hal ini mengakibatkan makin bertambahnya volume sampah yang dihasilkan dari pembangunan. Semakin berkembang suatu kota akibat pertambahan jumlah penduduk serta peningkatan aktivitas hidupnya menyebabkan masalah yang ditimbulkan.

\section{METODE}

Penelitian ini menggunakan metode survei analitik kolerasi dengan pendekatan cross sectional. Variabel independen adalah perilaku penggunaan APD dan variabel dependen adalah penularan penyakit kulit.

Populasi penelitian yaitu petugas TPS di Kecamatan Sawahan Surabaya sebanyak 80 orang. Sampel yaitu 67 responden sesuai dengan kriterian inklusi.

Instrumen penelitian ini menggunakan lembar kuesioner. Penelitian dilakukan pada bulan Juli 2015.

Data penelitian dianalisis dengan menggunakan uji Spearman Correlation Test dengan menggunakan tabel Chi-square.

\section{HASIL}

Tabel 1. Distribusi frekuensi karakteristik responden di Wilayah TPS

Kecamatan Sawahan Surabaya

\begin{tabular}{|c|c|c|c|}
\hline No. & Karakteristik & $\mathbf{n}$ & $\%$ \\
\hline \multirow[t]{3}{*}{1.} & Jenis Kelamin & & \\
\hline & Laki-laki & 59 & 88.06 \\
\hline & Perempuan & 8 & 11.94 \\
\hline \multirow[t]{5}{*}{2.} & Umur & & \\
\hline & 20-30 Tahun & 14 & 20.90 \\
\hline & 31-40 Tahun & 20 & 29.85 \\
\hline & 41-50 Tahun & 21 & 31.34 \\
\hline & $>50 \quad$ Tahun & 12 & 17.91 \\
\hline \multirow[t]{4}{*}{3.} & Pendidikan & & \\
\hline & SD & 46 & 68.65 \\
\hline & SMP & 16 & 23.88 \\
\hline & SMA & 5 & 7.46 \\
\hline \multirow[t]{5}{*}{4.} & $\begin{array}{l}\text { Penghasilan Per } \\
\text { Bulan }\end{array}$ & & \\
\hline & $<$ Rp. 500.000,- & 40 & 59.70 \\
\hline & $\begin{array}{l}\text { Rp. 500.000-- } \\
1.000 .000,-\end{array}$ & 17 & 25.37 \\
\hline & $\begin{array}{l}\text { Rp. } 1.000 .000,-- \\
2.000 .000,-\end{array}$ & 10 & 14.92 \\
\hline & $>$ Rp. 2.000.000,- & 0 & 0 \\
\hline
\end{tabular}

Tabel 1 menunjukkan bahwa responden yang diteliti sebagian besar berjenis kelamin laki-laki sebanyak 59 responden (88.06\%), sebagian besar responden berumur 41-50 tahun sebanyak 21 responden (31.34\%), sebagian besar responden berpendidikan Sekolah Dasar (SD) sebanyak 46 responden (68.65\%), sebagian besar responden berpenghasilan per bulan < Rp. 500.000,sebanyak 40 orang $(59.70 \%)$.

Tabel 2. Tabulasi silang penggunaan APD Petugas TPS dan terjadinya penyakit

\begin{tabular}{|c|c|c|c|c|c|c|}
\hline \multirow{3}{*}{ No } & \multirow{3}{*}{$\begin{array}{c}\text { Penularan } \\
\text { Penyakit }\end{array}$} & \multicolumn{4}{|c|}{ APD } & \multirow[t]{3}{*}{ Total } \\
\hline & & \multicolumn{2}{|c|}{ pakai } & \multicolumn{2}{|c|}{ tidak } & \\
\hline & & $\mathrm{n}$ & $\%$ & $\mathrm{n}$ & $\%$ & \\
\hline 1. & Menular & 2 & 3 & 57 & 85 & 59 \\
\hline \multirow[t]{2}{*}{2.} & Tidak & 6 & 9 & 2 & 3 & 8 \\
\hline & Total & 8 & & 59 & & 67 \\
\hline \multicolumn{7}{|c|}{ Uji Korelasi Spearman $\mathrm{p}=0.00, \mathrm{r}=0.761$} \\
\hline
\end{tabular}

Tabel 2 menunjukkan bahwa petugas TPS yang tidak menggunakan alat pelindung diri sebanyak 57 orang $(85 \%)$ terjadi penularan penyakit kulit, yang tidak menggunakan alat pelindung diri sebanyak 2 orang $(3 \%)$ tidak terjadi penularan penyakit kulit, yang menggunakan alat pelindung diri sebanyak 2 orang $(3 \%)$ terjadi penularan 
penyakit kulit, dan yang menggunakan alat pelindung diri sebanyak 6 orang (9\%) tidak terjadi penularan penyakit kulit. Hasil uji chisquare menunjukkan nilai $\mathrm{p}=0.00(\alpha<0.05)$ dan $\mathrm{r}=0.761$, sehingga dapat disimpulkan terdapat hubungan yang kuat antara perilaku pemakaian APD dengan penularan penyakit kulit pada petugas TPS.

\section{PEMBAHASAN}

Menurut peneliti, petugas TPS yang memiliki penggunaan APD yang aktif, maka bagian kulit tubuhnya akan terlindung dari bakteri dan berbagai penyebab gangguan kulit yang terdapat pada sampah sehari-hari, sehingga resiko terjadinya gangguan kulit berkurang. Demikian juga sebaliknya, petugas TPS yang perilaku penggunaan APD-nya tidak aktif maka bakteri dan berbagai penyebab gangguan kulit yang terdapat pada sampah akan dengan mudah mengkontaminasi bagian kulit yang tidak terlindung APD, sehingga akan menyebabkan gangguan pada kulit. ${ }^{6}$ Sampai saat ini banyak sekali ditemukan kesalahan dan kekurangan dalam menggunakan APD di berbagai perusahaan baik lokal maupun yang berskala international. Ada dua faktor utama yang melatar belakangi masalah ini yaitu rendahnya tanggung jawab management terhadap keselamatan dan kesehatan pekerja dan rendahnya tingkat kesadaran para pekerja dalam menggunakan APD.

Menurut teori Green dijelaskan bahwa perilaku petugas sanitasi dipengaruhi oleh faktor predisposing, faktor enabling, dan faktor reinforcing. Untuk faktor predisposing untuk melaksanakan upaya pengelolaan sampah medis dipengaruhi oleh umur, jenis kelamin, pengetahuan dan praktik. Perbedaan individual akan mempengaruhi dalam upaya penegelolaan sampah. Sedangkan pada faktor enabling yang memungkinkan terlaksananya pengelolaan sampah medis adalah tersedianya fasilitas misalnya sarung tangan, sepatu boot, dan kantong plastik. Faktor yang mendorong dalam kegiatan pengelolaan sampah medis adalah adanya petunjuk positif dari petugas sanitasi, teman kerja, peraturan, undangundang dan kebijakan dari pemerintah. ${ }^{5}$

Berdasarkan hasil penelitian tersebut dan diperkuat dengan teori diharapkan petugas sanitasi dapat meningkatkan lagi pengetahuan tentang pengelolaan sampah. Pemakaian APD harus menjadi kewajiban dan kebiasaan tenaga kerja sebagai perlindungan terakhir dalam upaya pencegahan kecelakaan dan penyakit akibat kerja (PAK). Pemakaian APD tersebut dapat mengurangi resiko paparan penularan penyakit kepada tenaga kerja. Kesadaran para pekerja akan penggunaan alat pelindung diri (APD) dalam bekerja ternyata masih sangat rendah.

\section{SIMPULAN}

Perilaku tidak menggunakan APD dapat meningkatkan risiko terjadinya penularan penyakit kulit, terlebih petugas TPS sangat rentan terhadap penyakit kulit disebabkan setiap hari bersentuhan langsung dengan sampah. Oleh sebab itu sangat penting bagi petugas TPS selalu menggunakan APD untuk meminimalkan risiko penularan penyakit kulit.

\section{SARAN}

Petugas TPS disarankan untuk menggunakan alat pelindung diri saat bekerja, supaya tidak tertular bakteri penyebab penyakit kulit yang dapat menghambat aktivitas pekerjaan sehari-hari. Serta menjaga kesehatan melalui kebersihan individu dengan cara mengendalikan kondisi lingkungan sekitar. Perlu adanya sosialisasi atau penyuluhan manfaat penggunaan APD dari dinas terkait sebagai upaya preventif dan promotif untuk meminimalkan risiko penularan penyakit kulit pada petugas TPS.

\section{KEPUSTAKAAN}

1. Arikunto, Suharsimi. 2006. Prosedur penelitian Suatu Pendekatan Praktik. Jakarta: Rineka Cipta, 2006.

2. Notoatmodjo, Soekidjo. 2010. Metodologi Penelitian Kesehatan. Jakarta: Rineka Cipta, 2010

3. Mubarak, Wahid I.2009.Ilmu Kesehatan Masyarakat Teori dan Aplikasi.Jakarta: Salemba Medika

4. Price, Sylvia A. 1995. Patofisiologi Konsep Klinis Proses-proses Penyakit. Jakarta: EGC

5. Watson, Roger. 2002. Anatomi \& Fisiologi untuk perawat. Edisi 10. Jakarta: EGC

6. Siregar, R.S. 2005, Penyakit Jamur Kulit. Jakarta: EGC 